\title{
Indole-3-carbinol: a plant hormone combatting cancer
}

\section{[version 1; peer review: 2 approved]}

\section{Ella Katz'1,2, Sophia Nisani ${ }^{1}$, Daniel A. Chamovitz (iD)1}

${ }^{1}$ School of Plant Sciences and Food Security, Tel Aviv University, Tel Aviv, Israel

${ }^{2}$ Department of Plant Sciences, University of California, Davis, USA

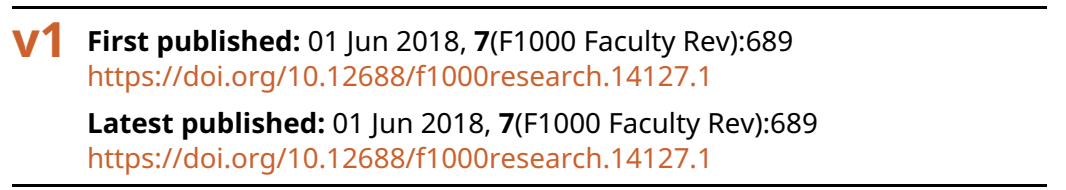

\section{Abstract}

A diet rich in cruciferous vegetables such as cauliflower, broccoli, and cabbage has long been considered healthy, and various epidemiological studies suggest that the consumption of cruciferous vegetables contributes to a cancer-protecting diet. While these vegetables contain a vast array of phytochemicals, the mechanism by which these vegetables counteract cancer is still largely unresolved. Numerous in situ studies have implicated indole-3-carbinol, a breakdown product of the glucosinolate indole-3-

ylmethylglucosinolate, as one of the phytochemicals with anti-cancer properties. Indole-3-carbinol influences a range of cellular processes, but the mechanisms by which it acts on cancer cells are slowly being revealed. Recent studies on the role of indole-3-carbinol in Arabidopsis opens the door for cross-kingdom comparisons that can help in understanding the roles of this important phytohormone in both plant biology and combatting cancer.

\section{Keywords}

glucosinolates, indole-3-carbinol, cancer prevention, cruciferous vegetables

\section{Open Peer Review \\ Approval Status \\ 1 \\ 2 \\ version 1 \\ 01 Jun 2018 \\ Faculty Reviews are review articles written by the prestigious Members of Faculty Opinions. The articles are commissioned and peer reviewed before publication to ensure that the final, published version is comprehensive and accessible. The reviewers who approved the final version are listed with their names and affiliations.}

1. Gary L. Firestone, University of California at Berkeley, Berkely, USA

2. Juan M. Zapata, CSIC-UAM, Madrid, Spain Any comments on the article can be found at the end of the article. 
Corresponding author: Daniel A. Chamovitz (dannyc@tauex.tau.ac.il)

Author roles: Katz E: Conceptualization, Writing - Original Draft Preparation, Writing - Review \& Editing; Nisani S: Investigation, Writing - Review \& Editing; Chamovitz DA: Project Administration, Supervision, Writing - Original Draft Preparation, Writing - Review \& Editing Competing interests: No competing interests were disclosed.

Grant information: Our research into the role of $\mathrm{I} C \mathrm{C}$ in Arabidopsis is funded by grants from the Binational Agricultural Research and Development Fund (BARD, IS-4505-12R and US-4846-15C).

The funders had no role in study design, data collection and analysis, decision to publish, or preparation of the manuscript.

Copyright: $\odot 2018$ Katz E et al. This is an open access article distributed under the terms of the Creative Commons Attribution License, which permits unrestricted use, distribution, and reproduction in any medium, provided the original work is properly cited.

How to cite this article: Katz E, Nisani S and Chamovitz DA. Indole-3-carbinol: a plant hormone combatting cancer [version 1; peer review: 2 approved] F1000Research 2018, 7(F1000 Faculty Rev):689 https://doi.org/10.12688/f1000research.14127.1

First published: 01 Jun 2018, 7(F1000 Faculty Rev):689 https://doi.org/10.12688/f1000research.14127.1 


\section{Introduction}

A diet rich in cruciferous vegetables such as cauliflower, broccoli, and cabbage has long been considered healthy. Even in ancient times, extracts from these vegetables were thought to have medicinal and curative properties, and both Pythagoras and Hippocrates understood the medicinal properties of mustard extracts ${ }^{1}$. In the $20^{\text {th }}$ century, epidemiological studies pointing to the protective properties of cruciferous vegetables in a cancerprotecting diet started to accumulate ${ }^{2}$. A meta-analysis of studies carried out over 18 years in Europe revealed an inverse association between weekly consumption of cruciferous vegetables and several common cancers, including colorectal, breast, kidney, and upper digestive tract cancers ${ }^{3}$. While these vegetables contain a vast array of phytochemicals ${ }^{4}$, the mechanism by which these vegetables counteract cancer is still largely unresolved.

The anticarcinogenic properties associated with crucifers are primarily attributed to the presence of glucosinolates, a family of secondary metabolites that are synthesized uniquely in this plant family and play a dominant role in plant defenses against insects ${ }^{5}$. Glucosinolates are derived from glucose and amino acids and contain various modifications to their side chain. The exact glucosinolate profile varies among crucifer species, and more than 140 glucosinolates have been characterized, including approximately 40 in Arabidopsis ${ }^{6,7}$. Herbivory or other tissue damage initiates the hydrolysis of glucosinolates by an endogenous plant $\beta$-thioglucosidase termed "myrosinase". Glucosinolates and myrosinase are stored in separate plant compartments and meet only following cell rupture. This separation is likely an adaptation to allow the targeted production of glucosinolate breakdown products, which are toxic to not only herbivores and pathogens but also the plants themselves. Further catalysis and spontaneous degradation results in the formation of nitriles, epithionitriles, oxazolidine-2-thiones, thiocyanates, and isothiocyanates ${ }^{8,9}$. These glucosinolate breakdown products cause the characteristic sharp taste of cruciferous vegetables and typically have a deterrent effect on generalist herbivores ${ }^{10-12}$.

Breakdown of indole-3-ylmethylglucosinolate (I3M-GS), one of the most widely distributed glucosinolates, leads to the formation of indole-3-acetonitrile (I3N) and indole-3-carbinol (I3C) (Figure 1$)^{13}$. I3C, in turn, can react with itself and a variety of other plant metabolites to form conjugates, some of which are shown in Figure 1. Most of these I3C conjugates have as-yet-unknown functions in plant metabolism, though, interestingly, another function of glucosinolate breakdown products may be to signal further plant defense responses ${ }^{14}$. Therefore, it is possible that I3M-GS breakdown also triggers other downstream responses in Arabidopsis and other crucifers.

From a dietary perspective, cooking vegetables affects their profile of glucosinolate breakdown ${ }^{15}$. Boiling leads to inactivation of the myrosinase enzyme but can also lead to a non-enzymatic breakdown of I3M-GS to I3C and $\mathrm{I} 3 \mathrm{~N}^{16}$. In addition, human gut microbes can lead to glucosinolate breakdown ${ }^{17}$.

\section{Indole-3-carbinol and cancer}

The glucosinolate breakdown products, rather than intact glucosinolates, primarily contribute to the anticarcinogenic effects of eating cabbage, broccoli, and related vegetables ${ }^{11,12,18}$. $\mathrm{I} 3 \mathrm{C}$ has long been studied regarding potential roles in cancer management ${ }^{19,20}$, and many studies showed that I3C suppresses the proliferation of various cancer cell lines, including breast, colon, prostate, and endometrial cancer cells (reviewed in 19,21). One example of its anti-proliferative properties comes from a study conducted on non-tumorigenic and tumorigenic breast epithelial cells (MCF10A and MCF10CA1a, respectively), which showed that $\mathrm{I} 3 \mathrm{C}$ induced apoptosis in the breast cancer cells but not in

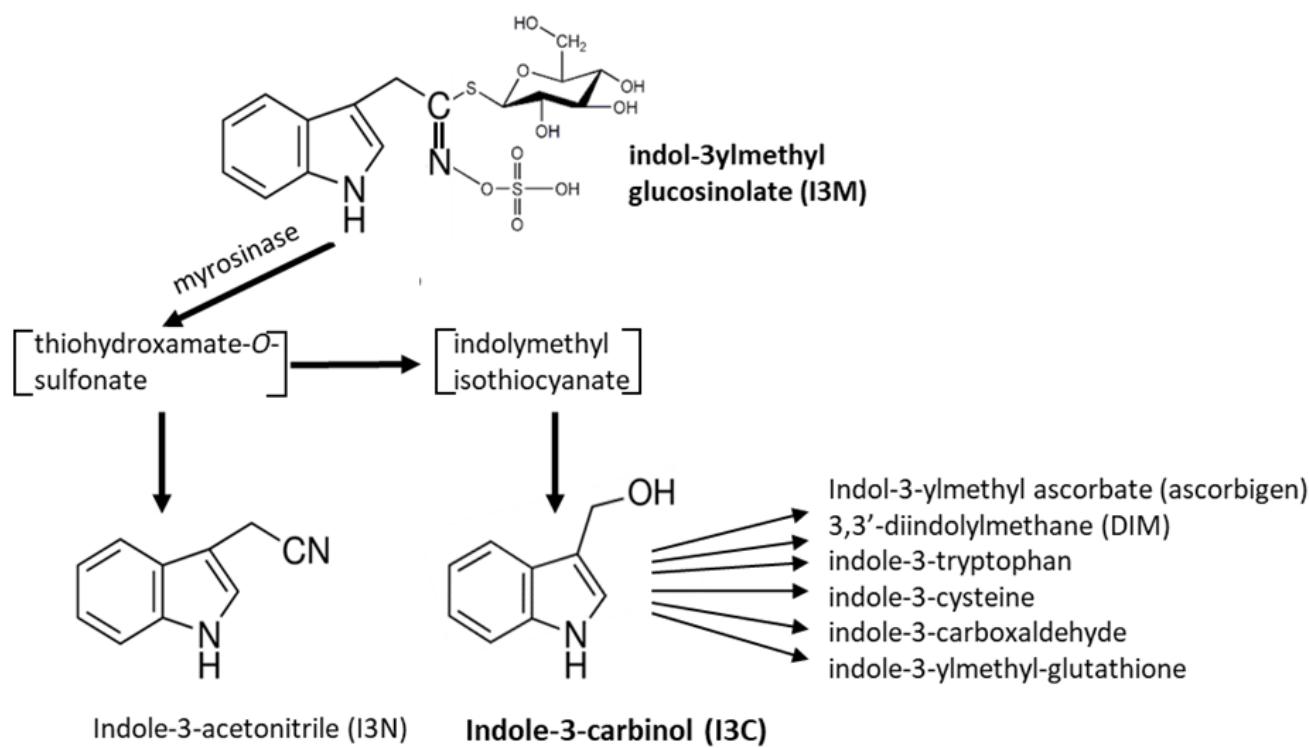

Figure 1. Myrosinase-catalyzed breakdown of indol-3-ylmethylglucosinolate (I3M-GS). Myrosinase-catalyzed breakdown of I3M-GS leads to the formation of unstable intermediates and then to indole-3-acetonitrile (I3N) and indole-3-carbionol (I3C). I3C reacts with itself and other plant metabolites to form a number of conjugates, some of which are shown. 
the non-tumorigenic breast epithelial cells ${ }^{22}$. I3C and one of its reaction products, diindolylmethane (DIM), were implicated in the induction of phase 1 detoxification enzymes, which can result in the breakdown of other dietary carcinogens. Both in situ and in vivo studies point to a role for I3C as a chemoprotective agent in breast and prostate cancer ${ }^{23}$.

The exact mechanisms by which I3C influences human cells are unclear, though direct interaction with a variety of signaling pathways has been proposed. The treatment of various cancer cells with I3C induces G1 cell cycle arrest ${ }^{24-30}$. Other studies pointed to a connection between treatment of $\mathrm{I} 3 \mathrm{C}$ and stimulation of apoptosis in several tumor cells $\mathrm{s}^{25,31-34}$. I3C also induced autophagy in different cell lines. For example, the treatment of human colon cancer HT-29 cells with I3C and genistin induced autophagy and suppressed the cells' viability ${ }^{35}$. The treatment of human breast cancer cell lines with a cyclic tetrameric derivative of $\mathrm{I} 3 \mathrm{C}$ resulted in upregulation of key signaling molecules involved in endoplasmic reticulum stress response and autophagy ${ }^{36}$. I3C also has the potential to modulate the metabolism of estrogen, and, through this, it may lower the risk of hormone-dependent cancers ${ }^{37-39}$. In addition, I3C inhibited tumor invasion and metastasis ${ }^{40-44}$ and modulated the activity of several transcription factors and various protein kinases ${ }^{21}$. Interestingly, I3C may also be involved in the inhibition of amyloid fibril formation ${ }^{45}$. I3C was proposed to act as an angiogenesis agent, as it was shown to inhibit the development of new blood vessels ${ }^{46}$. A number of studies have shown that $\mathrm{I} 3 \mathrm{C}$ treatment leads to various changes in gene expression, including changes in key microRNAs (reviewed in 47). The complex mixture of indole metabolites found in cruciferous vegetables likely has synergistic anticarcinogenic effects that are not seen in experiments with individual compounds ${ }^{32}$.

In vivo studies showed that $\mathrm{I} 3 \mathrm{C}$ inhibits the development of different cancers in several animals when given before or in parallel to a carcinogen. However, when I3C was given to the animals after the carcinogen, I3C promoted carcinogenesis ${ }^{48}$. This concern regarding the long-term effects of I3C treatment on cancer risk in humans resulted in some caution in the use of I3C as a dietary supplement in cancer management protocols ${ }^{49,50}$.

Mammalian cellular processes attributed to I3C action are as diverse as the different phenotypes presented by the many cancers studied. Indeed, focusing on the effects of I3C on one type of cancer (e.g. breast cancer) may present pleiotropic effects for $\mathrm{I} 3 \mathrm{C}$ on multiple molecular targets (reviewed in 51) that may be distinct from those presented in another cancer type. While not often considered, to get a different perspective on the action of $\mathrm{I} 3 \mathrm{C}$ in cells in general, it may be instructive to learn from the activity of $\mathrm{I} 3 \mathrm{C}$ in plants.

\section{Indole-3-carbinol and plants}

The model plant Arabidopsis thaliana provides an excellent system for elucidating the molecular mechanisms involved in $\mathrm{I} 3 \mathrm{C}$ action, as 1) it produces $\mathrm{I} 3 \mathrm{C}$ endogenously following herbivory, 2) small amounts of I3C are produced constitutively in the roots, hinting at an endogenous role in maintaining homeostasis, and 3) its short life cycle and small stature coupled with advanced available genetic and genomic resources make Arabidopsis an excellent model system not only for plant biology but also for eukaryotic research in general ${ }^{52}$.

While the role of $\mathrm{I} 3 \mathrm{C}$ in deterring herbivores is well studied $^{53}$, as is the biochemical pathway leading to the production of $\mathrm{I}^{2} \mathrm{C}^{13}$, the secondary responses in plants induced by $\mathrm{I} 3 \mathrm{C}$ are only now starting to be revealed. Our recent studies highlight that $\mathrm{I} 3 \mathrm{C}$ is not only a defensive chemical targeting herbivores but also a signaling molecule modulating different cellular and developmental pathways.

Using Arabidopsis as a model system, we showed that exogenously applied I3C rapidly and reversibly inhibited root elongation in a dose-dependent manner ${ }^{54}$. This inhibition was accompanied by three $\mathrm{I} 3 \mathrm{C}$-induced responses that are relevant for our understanding of $\mathrm{I} 3 \mathrm{C}$ activity in inhibiting cancer.

First, the application of I3C led to a cessation of cell division in the root meristem (Figure 2A). While normally a number of CycB1-expressing cells are visible in the root meristem, following $\mathrm{I} 3 \mathrm{C}$ treatment, no $\mathrm{CycB} 1$-containing cells were detected, indicating a cessation of cell division. This conclusion is supported by transcript-profiling results showing the downregulation of cell cycle genes six hours following exposure to $\mathrm{I}^{3} \mathrm{C}^{55}$.

Fluorescence-activated cell sorting (FACS) analysis on nuclei isolated from root tips further indicates a stoppage of the cell cycle. As seen in Figure 2B, three distinct populations of nuclei are detected in untreated roots, corresponding to $2 n, 4 n$, and $8 n$ nuclei. However, following treatment with $\mathrm{I} 3 \mathrm{C}$, there is a progressive loss of the $4 n$ and $8 n$ populations, with a concurrent increase in cells with increased side-scatter (population B).

Second, the application of I3C led to a loss of auxin (indole-3acetic acid [IAA]) activity in the root meristem ${ }^{54}$. Auxin is the most central plant hormone, controlling nearly all aspects of plant growth and development ${ }^{56}$. I3C affects plant growth and development by directly modulating auxin signaling. I3C antagonized a number of auxin-induced growth phenotypes, including inhibition of root elongation, formation of root hairs, and secondary root branching. I3C directly interferes with the auxin-dependent binding of the auxin-receptor Transport Inhibitor Response (TIR1) to two of its substrates ${ }^{54}$. The TIR1 auxin receptor is an F-box-containing subunit of the SCF (Skp, Cullin, F-box) E3 ubiquitin ligase complex. Auxin binding to the $\mathrm{SCF}^{\mathrm{TIR} 1 / \mathrm{AFB}}$ promotes the degradation of auxin/ indole-3-acetic acid (Aux/IAA) transcriptional repressors and through this regulates the transcription of the auxin-induced genes $^{57}$. I3C inhibits the auxin-dependent dimerization of the receptor with its substrates by competing with auxin for the same binding site in TIR1.

The third I3C-induced response relevant for our understanding of I3C activity in inhibiting cancer is autophagy. Exposure of Arabidopsis roots to $\mathrm{I} 3 \mathrm{C}$ leads to the induction of autophagy ${ }^{58}$. This autophagy is not general, aimed at bulk degradation of general cytoplasmic content for recycling, such as that occuring 

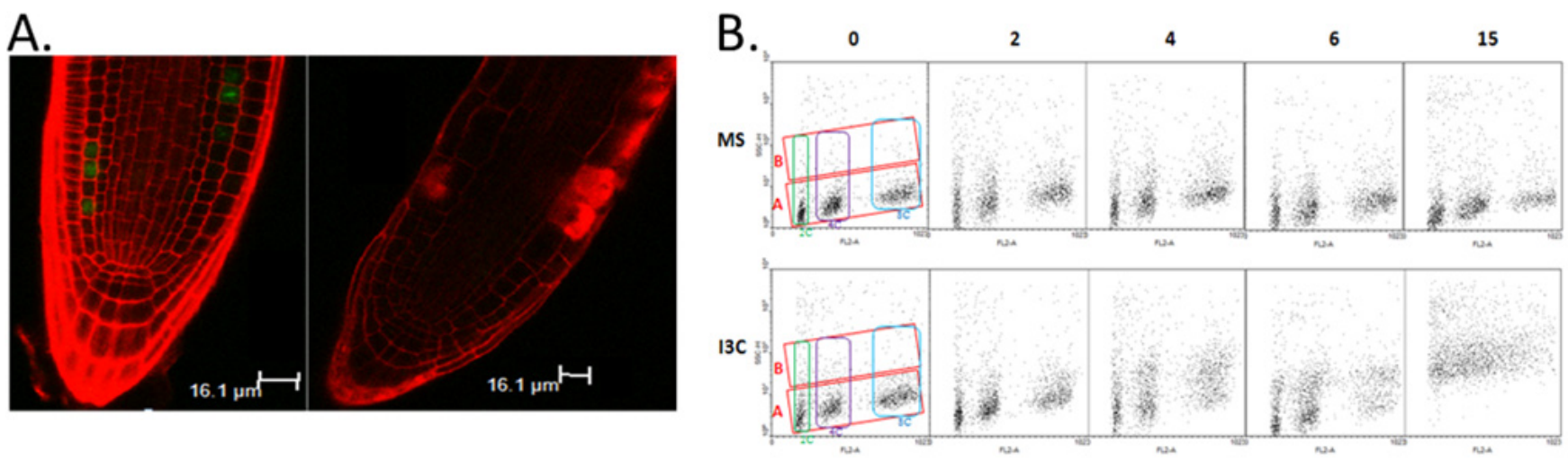

Figure 2. Indole-3-carbionol (I3C) affects cell cycle and nuclear complexity in the Arabidopsis root meristem. A. Confocal imaging reveals a lack of Cyclin B-GFP-expressing cells following I3C treatment. Seedlings expressing Cyclin B-GFP were grown on Murashige and Skoog (MS) medium for 4 days, treated with MS (left panel) or 500 um I3C (right panel) for 6 hours, and imaged using confocal microscopy. Cell walls were stained using propidium iodide. B. Fluorescence-activated cell sorting (FACS) analysis reveals changes in nuclear complexity following I3C treatment. Nuclei were isolated from Arabidopsis roots treated with MS or MS plus I3C for the marked times between 0 and 15 hours and analyzed by FACS for DNA content (FL2-A = propidium iodide fluorescence) and nuclear complexity (SCC-H = light side scatter). The green, purple, and blue boxes represent the populations differing according to nuclear content, $2 \mathrm{n}$, $4 \mathrm{n}$, and the endoreplication population (8n), respectively. The red boxes represent two populations of nuclei ("A" and "B") that differ according to side scatter.

under starvation conditions, but rather specific. Specific autophagy targets damaged proteins and other cellular components for degradation $^{59}$ and is seen in the co-localization of the GFPAtATG8A and mCherry-AtNBR1 marker proteins in autophagosomes following I3C treatment. The I3C-induced autophagy targets the TIR1 auxin receptor, thus connecting I3C-dependent inhibition of auxin signaling ${ }^{55}$ and the $\mathrm{I} 3 \mathrm{C}$ induction of autophagy ${ }^{58}$.

These two I3C-dependent processes were detected in roots not only after direct exposure to exogenously applied I3C but also following the treatment of leaves with I3C. Most importantly, leaf-wounding also induced autophagy and inhibited the auxin response in the root, and this effect of wounding was lost in glucosinolate-defective mutants. This indicates that an $\mathrm{I} 3 \mathrm{C}$ dependent signal is transported from leaves to the root meristem where auxin signaling is inhibited and autophagy is induced. Thus, I3C is not only a defensive metabolite that repels insects but also involved in long-distance communication regulating growth and development in plants.

\section{Indole-3-carbinol, autophagy, and protein turnover}

The connection between I3C and autophagy is quite interesting, as this connection was also found in several human cancer cells, as described earlier ${ }^{35,36}$. The process of autophagy involves the degradation of unnecessary or dysfunctional cellular components through the actions of lysosomes (in mammals) or vacuoles (in plants). This process is evolutionarily conserved among eukaryotes, and its mechanism is well elucidated ${ }^{60,61}$. In the context of cancer, autophagy can be viewed as a "doubleedged sword". The activation of autophagy may function as a tumor suppressor (by degrading the defective organelles and cellular component) or can be exploited by the cancer cells to generate nutrients and energy during periods of starvation ${ }^{62}$.
Although I3C-induced autophagy was detected in both plants and animals, the direct signaling mechanism has yet to be elucidated. However, this might hint at a shared signaling mechanism for both plants and humans. Thus, not only is it instructive for cancer biologists to learn from the activity of $\mathrm{I} 3 \mathrm{C}$ in plants but also plant biologists have much to gain from a closer understanding of the mechanistic studies of cancer biologists.

To date, only a few I3C-binding proteins have been identified. In human cells, the enzyme elastase, which mediates the conversion of cyclin E from a higher- to a lower-molecular-weight form associated with cancer cell proliferation, was the first identified specific target protein for $\mathrm{I}^{3} \mathrm{C}^{63}$. I3C treatments also inhibited elastase-dependent cleavage of an additional substrate, membrane-associated CD40, a member of the tumor necrosis factor (TNF) receptor superfamily ${ }^{64}$. Thus, the I3C-elastase nexus may aid in the development of targeted therapies of human breast cancers where high elastase levels are correlated with poor prognosis.

The only I3C-binding protein identified in plants to date is the TIR1 F-box protein. While auxin is a plant-specific hormone, SCF complexes also exist in mammals and play important roles in many mammalian functions ${ }^{65}$. TIR1 is related to the human protein SKP2 ${ }^{66}$, so conceivably $\mathrm{I} 3 \mathrm{C}$ could regulate protein turnover in mammals as well. This conjecture is supported by studies which showed that I3C targets and inhibits a different E3 ubiquitin ligase, NEDD4-1 (Neural precursor cell Expressed Developmentally Down regulated gene 4-1) in human melanoma cells ${ }^{67,68}$. Thus, an I3C-bound, inhibited NEDD4 would need to be cleared from the cell, and conceivably this could occur via specific autophagy, just as I3C-bound, inhibited TIR1 is targeted in plant roots for clearing by specific autophagy. As NEDD4 is frequently overexpressed in different types of human cancers ${ }^{69}$, 
I3C could be a potential therapeutic agent inhibiting the activity of the over-accumulated E3 ligase.

While plants do not develop metastatic cancer as mammals do, plants can develop tumors. Plants and animals share numerous pathways and signaling cascades ${ }^{70}$, and approximately $70 \%$ of the genes implicated in cancer have homologs in the Arabidopsis thaliana genome, similar to the percentages of human cancer genes in other established systems such as Drosophila melanogaster, Caenorhabditis elegans, and Saccharomyces cerevisiae ${ }^{52}$. Furthermore, while plants and animals obviously have independent hormonal regulatory mechanisms, some similarity and cross reactivity exists between the kingdoms. Plants produce phytoestrogens and other steroid hormones, which also affect human hormone signaling, as well as a number of putative steroid hormone-binding proteins ${ }^{71-75}$. Thus, the study of $\mathrm{I} 3 \mathrm{C}$ in plants can have direct implications for further understanding the role of $\mathrm{I} 3 \mathrm{C}$ and perhaps controlling cancer in humans.

\section{Competing interests}

The authors declare that they have no competing interests.

\section{Grant information}

Our research into the role of $\mathrm{I} 3 \mathrm{C}$ in Arabidopsis is funded by grants from the Binational Agricultural Research and Development Fund (BARD, IS-4505-12R and US-4846-15C).

The funders had no role in study design, data collection and analysis, decision to publish, or preparation of the manuscript.
1. Fenwick GR, Heaney RK: Glucosinolates and their breakdown products in cruciferous crops, foods and feedingstuffs. Food Chem. 1983; 11(4): 249-71. Publisher Full Text

2. Verhoeven DT, Goldbohm RA, van Poppel G, et al: Epidemiological studies on brassica vegetables and cancer risk. Cancer Epidemiol Biomarkers Prev. 1996; 5(9): 733-48. PubMed Abstract

3. Bosetti $\mathrm{C}$, Filomeno $\mathrm{M}$, Riso $\mathrm{P}$, et al:: Cruciferous vegetables and cancer risk in a network of case-control studies. Ann Oncol. 2012; 23(8): 2198-203. PubMed Abstract | Publisher Full Text

4. Björkman M, Klingen I, Birch AN, et al.: Phytochemicals of Brassicaceae in plant protection and human health--influences of climate, environment and agronomic practice. Phytochemistry. 2011; 72(7): 538-56. PubMed Abstract | Publisher Full Text

5. Fahey JW, Zalcmann AT, Talalay P: The chemical diversity and distribution of glucosinolates and isothiocyanates among plants. Phytochemistry. 2001; 56(1): 5-51.

PubMed Abstract | Publisher Full Text

6. $\quad F$ Kliebenstein DJ, Kroymann J, Brown P, et al:: Genetic control of natural variation in Arabidopsis glucosinolate accumulation. Plant Physiol. 2001; 126(2): 811-25.

PubMed Abstract | Publisher Full Text | Free Full Text | F1000 Recommendation

7. Reichelt M, Brown PD, Schneider B, et al:: Benzoic acid glucosinolate esters and other glucosinolates from Arabidopsis thaliana. Phytochemistry. 2002; 59(6): 663-71. PubMed Abstract | Publisher Full Text

8. Halkier BA, Gershenzon J: Biology and biochemistry of glucosinolates. Annu Rev Plant Biol. 2006; 57: 303-33.

PubMed Abstract | Publisher Full Text

9. Sønderby IE, Geu-Flores F, Halkier BA: Biosynthesis of glucosinolates--gene discovery and beyond. Trends Plant Sci. 2010; 15(5): 283-90. PubMed Abstract | Publisher Full Text

10. Bones AM, Rossiter JT: The enzymic and chemically induced decomposition of glucosinolates. Phytochemistry. 2006; 67(11): 1053-67. PubMed Abstract | Publisher Full Text

11. Keck AS, Finley JW: Cruciferous vegetables: cancer protective mechanisms of glucosinolate hydrolysis products and selenium. Integr Cancer Ther. 2004; 3(1): 5-12.

PubMed Abstract | Publisher Full Text

12. Kim YS, Milner JA: Targets for indole-3-carbinol in cancer prevention. J Nutr Biochem. 2005; 16(2): 65-73. PubMed Abstract | Publisher Full Text

13. Agerbirk N, De Vos M, Kim JH, et al.: Indole glucosinolate breakdown and its biological effects. Phytochem Rev. 2009; 8: 101-20. Publisher Full Tex

14. F Clay NK, Adio AM, Denoux C, et al.: Glucosinolate metabolites required for an Arabidopsis innate immune response. Science. 2009; 323(5910): 95-101. PubMed Abstract | Publisher Full Text | Free Full Text | F1000 Recommendation

15. F Palermo M, Pellegrini N, Fogliano V: The effect of cooking on the phytochemical content of vegetables. J Sci Food Agric. 2014; 94(6): 1057-70. PubMed Abstract | Publisher Full Text | F1000 Recommendation
16. Campbell LD, Slominski BA: Extent of thermal decomposition of indole glucosinolates during the processing of canola seed. J Am Oil Chem Soc. 1990; 67(2): 73-5

Publisher Full Text

17. Shapiro TA, Fahey JW, Wade KL, et al:: Human metabolism and excretion of cancer chemoprotective glucosinolates and isothiocyanates of cruciferous vegetables. Cancer Epidemiol Biomarkers Prev. 1998; 7(12): 1091-100. PubMed Abstract

18. Bones AM, Rossiter JT: The myrosinase-glucosinolate system, its organisation and biochemistry. Physiol Plant. 1996; 97(1): 194-208. Publisher Full Text

19. F Fujioka N, Fritz V, Upadhyaya $P$, et al.: Research on cruciferous vegetables, indole-3-carbinol, and cancer prevention: A tribute to Lee W. Wattenberg. Mol Nutr Food Res. 2016; 60(6): 1228-38.

PubMed Abstract | Publisher Full Text | F1000 Recommendation

20. Verhoeven DT, Verhagen H, Goldbohm RA, et al:: A review of mechanisms underlying anticarcinogenicity by brassica vegetables. Chem Biol Interact. 1997; 103(2): 79-129.

PubMed Abstract | Publisher Full Text

21. Aggarwal BB, Ichikawa $\mathrm{H}$ : Molecular targets and anticancer potential of indole3-carbinol and its derivatives. Cell Cycle. 2005; 4(9): 1201-15.

PubMed Abstract | Publisher Full Text

22. Rahman KM, Aranha O, Sarkar FH: Indole-3-carbinol (I3C) induces apoptosis in tumorigenic but not in nontumorigenic breast epithelial cells. Nutr Cancer. 2003; 45(1): 101-12.

PubMed Abstract | Publisher Full Text

23. Bradlow HL: Review. Indole-3-carbinol as a chemoprotective agent in breast and prostate cancer. In Vivo. 2008; 22(4): 441-5.

PubMed Abstract

24. Cover CM, Hsieh SJ, Tran SH, et al.: Indole-3-carbinol inhibits the expression of cyclin-dependent kinase- 6 and induces a G1 cell cycle arrest of human breast cancer cells independent of estrogen receptor signaling. J Biol Chem. 1998; 273(7): 3838-47.

PubMed Abstract | Publisher Full Text

25. Chinni SR, Li Y, Upadhyay S, et al.: Indole-3-carbinol (I3C) induced cell growth inhibition, G1 cell cycle arrest and apoptosis in prostate cancer cells. Oncogene. 2001; 20(23): 2927-36. PubMed Abstract | Publisher Full Text

26. Brandi G, Paiardini M, Cervasi B, et al:: A new indole-3-carbinol tetrameric derivative inhibits cyclin-dependent kinase 6 expression, and induces G1 cell cycle arrest in both estrogen-dependent and estrogen-independent breast cancer cell lines. Cancer Res. 2003; 63(14): 4028-36. PubMed Abstract

27. Zhang J, Hsu B A JC, Kinseth B A MA, et al.: Indole-3-carbinol induces a G1 cell cycle arrest and inhibits prostate-specific antigen production in human LNCaP prostate carcinoma cells. Cancer. 2003; 98(11): 2511-20. PubMed Abstract | Publisher Full Text

28. Cover CM, Hsieh SJ, Cram EJ, et al.: Indole-3-carbinol and tamoxifen cooperate to arrest the cell cycle of MCF-7 human breast cancer cells. Cancer Res. 1999; 59(6): 1244-51.

PubMed Abstract 
29. Matsuzaki Y, Koyama M, Hitomi T, et al.: Indole-3-carbinol activates the cyclindependent kinase inhibitor p15 1NK4b gene. FEBS Lett. 2004; 576(1-2): 137-40. PubMed Abstract | Publisher Full Text

30. Chen Z, Tao ZZ, Chen SM, et al.: Indole-3-carbinol inhibits nasopharyngeal carcinoma growth through cell cycle arrest in vivo and in vitro. PLoS One. 2013; 8(12): e82288.

PubMed Abstract | Publisher Full Text | Free Full Text

31. Ge X, Fares FA, Yannai S: Induction of apoptosis in MCF-7 cells by indole-3carbinol is independent of p53 and bax. Anticancer Res. 1999; 19(4B): 3199-203. PubMed Abstract

32. Bonnesen C, Eggleston IM, Hayes JD: Dietary indoles and isothiocyanates that are generated from cruciferous vegetables can both stimulate apoptosis and confer protection against DNA damage in human colon cell lines. Cancer Res. 2001; 61(16): 6120-30.

PubMed Abstract

33. F Safa M, Jafari L, Alikarami F, et al.: Indole-3-carbinol induces apoptosis of chronic myelogenous leukemia cells through suppression of STAT5 and Akt signaling pathways. Tumour Biol. 2017; 39(6): 1010428317705768. PubMed Abstract | Publisher Full Text | F1000 Recommendation

34. F Perez-Chacon G, de Los Rios C, Zapata JM: Indole-3-carbinol induces cMYC and IAP-family downmodulation and promotes apoptosis of Epstein-Barr virus (EBV)-positive but not of EBV-negative Burkitt's lymphoma cell lines. Pharmacol Res. 2014; 89: 46-56.

PubMed Abstract | Publisher Full Text | F1000 Recommendation

35. Nakamura $Y$, Yogosawa S, Izutani $Y$, et al:: A combination of indol-3-carbinol and genistein synergistically induces apoptosis in human colon cancer HT-29 cells by inhibiting Akt phosphorylation and progression of autophagy. $\mathrm{MO}$ Cancer. 2009; 8: 100.

PubMed Abstract | Publisher Full Text | Free Full Text

36. Galluzzi L, De Santi M, Crinelli R, et al.: Induction of endoplasmic reticulum stress response by the indole-3-carbinol cyclic tetrameric derivative CTet in human breast cancer cell lines. PLoS One. 2012; 7(8): e43249.

PubMed Abstract | Publisher Full Text | Free Full Text

37. Telang NT, Katdare M, Bradlow HL, et al:: Inhibition of proliferation and modulation of estradiol metabolism: novel mechanisms for breast cancer prevention by the phytochemical indole-3-carbinol. Proc Soc Exp Biol Med. 1997; 216(2): 246-52.

PubMed Abstract | Publisher Full Text

38. Meng Q, Yuan F, Goldberg ID, et al:: Indole-3-carbinol is a negative regulator of estrogen receptor-alpha signaling in human tumor cells. J Nutr. 2000; 130(12): 2927-31.

PubMed Abstract | Publisher Full Tex

39. Riby JE, Feng C, Chang YC, et al:: The major cyclic trimeric product of indole3-carbinol is a strong agonist of the estrogen receptor signaling pathway. Biochemistry. 2000; 39(5): 910-8.

PubMed Abstract | Publisher Full Text

40. Meng Q, Goldberg ID, Rosen EM, et al:: Inhibitory effects of Indole-3-carbinol on invasion and migration in human breast cancer cells. Breast Cancer Res Treat 2000; 63(2): 147-52.

PubMed Abstract | Publisher Full Text

41. Meng Q, Qi M, Chen DZ, et al.: Suppression of breast cancer invasion and migration by indole-3-carbinol: associated with up-regulation of BRCA1 and E-cadherin/catenin complexes. J Mol Med (Berl). 2000; 78(3): 155-65. PubMed Abstract | Publisher Full Text

42. Firestone GL, Bjeldanes LF: Indole-3-carbinol and 3-3'-diindolylmethan antiproliferative signaling pathways control cell-cycle gene transcription in human breast cancer cells by regulating promoter-Sp1 transcription factor interactions. J Nutr. 2003; 133(7 Suppl): 2448S-55.

PubMed Abstract | Publisher Full Text

43. Sarkar FH, Li Y: Indole-3-carbinol and prostate cancer. J Nutr. 2004;

134(12 Suppl): 3493S-8

PubMed Abstract | Publisher Full Text

44. Fan S, Meng Q, Auborn K, et al:: BRCA1 and BRCA2 as molecular targets for phytochemicals indole-3-carbinol and genistein in breast and prostate cance cells. Br J Cancer. 2006; 94(3): 407-26.

PubMed Abstract | Publisher Full Text | Free Full Text

45. Cohen T, Frydman-Marom A, Rechter M, et al:: Inhibition of amyloid fibri formation and cytotoxicity by hydroxyindole derivatives. Biochemistry. 2006; 45(15): 4727-35.

PubMed Abstract | Publisher Full Text

46. Chang $X$, Tou JC, Hong $C$, et al:: 3,3'-Diindolylmethane inhibits angiogenesis and the growth of transplantable human breast carcinoma in athymic mice. Carcinogenesis. 2005; 26(4): 771-8. PubMed Abstract | Publisher Full Text

47. Phuah $\mathrm{NH}$, Nagoor $\mathrm{NH}$ : Regulation of microRNAs by natural agents: new strategies in cancer therapies. Biomed Res Int. 2014; 2014: 804510. PubMed Abstract | Publisher Full Text | Free Full Text

48. Higdon JV, Delage B, Williams DE, et al.: Cruciferous vegetables and human cancer risk: epidemiologic evidence and mechanistic basis. Pharmacol Res. 2007; 55(3): 224-36.

PubMed Abstract | Publisher Full Text | Free Full Text

49. Dashwood RH: Indole-3-carbinol: anticarcinogen or tumor promoter in brassica vegetables? Chem Biol Interact. 1998; 110(1-2): 1-5.

PubMed Abstract | Publisher Full Text
50. Lee BM, Park K: Beneficial and adverse effects of chemopreventive agents. Mutat Res. 2003: 523-524: 265-78.

PubMed Abstract | Publisher Full Tex

51. Weng JR, Tsai CH, Kulp SK, et al.: Indole-3-carbinol as a chemopreventive and anti-cancer agent. Cancer Lett. 2008; 262(2): 153-63. PubMed Abstract | Publisher Full Text | Free Full Text

52. Jones AM, Chory J, Dangl JL, et al:: The impact of Arabidopsis on human health: diversifying our portfolio. Cell. 2008; 133(6): 939-43. PubMed Abstract | Publisher Full Text | Free Full Text

53. Kim JH, Lee BW, Schroeder FC, et al:: Identification of indole glucosinolate breakdown products with antifeedant effects on Myzus persicae (green peach aphid). Plant J. 2008; 54(6): 1015-26.

PubMed Abstract | Publisher Full Tex

54. Katz E, Nisani S, Yadav BS, et al:: The glucosinolate breakdown product indole3-carbinol acts as an auxin antagonist in roots of Arabidopsis thaliana. Plant $\mathrm{J}$. 2015; 82(4): 547-55.

PubMed Abstract | Publisher Full Tex

55. Katz E, Nisani S, Sela M, et al: The effect of indole-3-carbinol on PIN1 and PIN2 in Arabidopsis roots. Plant Signal Behav. 2015; 10(9): e1062200. PubMed Abstract | Publisher Full Text | Free Full Text

56. Zažímalová E, Petrášek J, Benková E: Auxin and Its Role in Plant Development Vienna: Springer Vienna; 2014

Publisher Full Text

57. F Dharmasiri N, Dharmasiri S, Estelle M: The F-box protein TIR1 is an auxin receptor. Nature. 2005; 435(7041): 441-5. PubMed Abstract | Publisher Full Text | F1000 Recommendation

58. Katz E, Chamovitz DA: Wounding of Arabidopsis leaves induces indole-3carbinol-dependent autophagy in roots of Arabidopsis thaliana. Plant J. 2017; 91(5): 779-87.

PubMed Abstract | Publisher Full Text

59. Svenning S, Lamark T, Krause K, et al:: Plant NBR1 is a selective autophagy substrate and a functional hybrid of the mammalian autophagic adapters NBR1 and p62/SQSTM1. Autophagy. 2011; 7(9): 993-1010. PubMed Abstract | Publisher Full Text | Free Full Text

60. Yang Z, Klionsky DJ: Mammalian autophagy: core molecular machinery and signaling regulation. Curr Opin Cell Biol. 2010; 22(2): 124-31. PubMed Abstract | Publisher Full Text | Free Full Text

61. F Michaeli S, Galili G, Genschik P, et al:: Autophagy in Plants--What's New on the Menu? Trends Plant Sci. 2016; 21(2): 134-44. PubMed Abstract | Publisher Full Text | F1000 Recommendation

62. Carew JS, Kelly KR, Nawrocki ST: Autophagy as a target for cancer therapy: new developments. Cancer Manag Res. 2012; 4: 357-65. PubMed Abstract | Publisher Full Text |Free Full Text

63. Nguyen HH, Aronchik I, Brar GA, et al.: The dietary phytochemical indole-3carbinol is a natural elastase enzymatic inhibitor that disrupts cyclin $E$ protein processing. Proc Natl Acad Sci U S A. 2008; 105(50): 19750-5. PubMed Abstract | Publisher Full Text | Free Full Text

64. Aronchik I, Bjeldanes LF, Firestone GL: Direct inhibition of elastase activity by indole-3-carbinol triggers a CD40-TRAF regulatory cascade that disrupts NF-kappaB transcriptional activity in human breast cancer cells. Cancer Res. 2010; 70(12): 4961-71.

PubMed Abstract | Publisher Full Text

65. Cardozo T, Pagano M: The SCF ubiquitin ligase: insights into a molecular machine. Nat Rev Mol Cell Biol. 2004; 5(9): 739-51.

PubMed Abstract | Publisher Full Text

66. Ruegger M, Dewey E, Gray WM, et al:: The TIR1 protein of Arabidopsis functions in auxin response and is related to human SKP2 and yeast grr1p. Genes Dev. 1998; 12(2): 198-207.

PubMed Abstract | Publisher Full Text | Free Full Text

67. F Aronchik I, Kundu A, Quirit JG, et al.: The antiproliferative response of indole-3-carbinol in human melanoma cells is triggered by an interaction with NEDD4-1 and disruption of wild-type PTEN degradation. Mol Cancer Res. 2014; 12(11): 1621-34.

PubMed Abstract | Publisher Full Text | Free Full Text | F1000 Recommendation

68. F Quirit JG, Lavrenov SN, Poindexter K, et al.: Indole-3-carbinol (I3C) analogues are potent small molecule inhibitors of NEDD4-1 ubiquiti ligase activity that disrupt proliferation of human melanoma cells. Biochem Pharmacol. 2017; 127: 13-27.

PubMed Abstract | Publisher Full Text | F1000 Recommendation

69. F Ye X, Wang L, Shang B, et al:: NEDD4: a promising target for cance therapy. Curr Cancer Drug Targets. 2014; 14(6): 549-56.

PubMed Abstract | Publisher Full Text | Free Full Text | F1000 Recommendation

70. Trapp O, Seeliger K, Puchta H: Homologs of breast cancer genes in plants. Front Plant Sci. 2011; 2: 19

PubMed Abstract | Publisher Full Text | Free Full Tex

71. F Hsieh CJ, Hsu YL, Huang YF, et al:: Molecular Mechanisms of Anticancer Effects of Phytoestrogens in Breast Cancer. Curr Protein Pept Sci. 2018; 19(3): 323-32.

PubMed Abstract | Publisher Full Text | F1000 Recommendation

72. Vert G, Nemhauser JL, Geldner N, et al.: Molecular mechanisms of steroid hormone signaling in plants. Annu Rev Cell Dev Biol. 2005; 21: 177-201. PubMed Abstract | Publisher Full Text 
riet C, Russinova E, Reuzeau C: From squalene to brassinolide: the steroid metabolic and signaling pathways across the plant kingdom. Mol Plant. 2013 6(6): 1738-57.

PubMed Abstract | Publisher Full Text

74. Janeczko A: The presence and activity of progesterone in the plant kingdom.
Steroids. 2012; 77(3): 169-73. PubMed Abstract | Publisher Full Text

75. Yang $\mathrm{XH}, \mathrm{Xu} \mathrm{ZH}$, Xue HW: Arabidopsis membrane steroid binding protein 1 is involved in inhibition of cell elongation. Plant Cell. 2005; 17(1): 116-31. PubMed Abstract | Publisher Full Text | Free Full Text 


\section{Open Peer Review}

\section{Current Peer Review Status:}

\section{Editorial Note on the Review Process}

Faculty Reviews are review articles written by the prestigious Members of Faculty Opinions. The articles are commissioned and peer reviewed before publication to ensure that the final, published version is comprehensive and accessible. The reviewers who approved the final version are listed with their names and affiliations.

\section{The reviewers who approved this article are:}

\section{Version 1}

\section{Juan M. Zapata}

Instituto de Investigaciones Biomédicas "Alberto Sols", CSIC-UAM, Madrid, Spain

Competing Interests: No competing interests were disclosed.

\section{Gary L. Firestone}

Department of Molecular and Cell Biology and the Cancer Research Laboratory, University of California at Berkeley, Berkely, California, USA

Competing Interests: No competing interests were disclosed.

The benefits of publishing with F1000Research:

- Your article is published within days, with no editorial bias

- You can publish traditional articles, null/negative results, case reports, data notes and more

- The peer review process is transparent and collaborative

- Your article is indexed in PubMed after passing peer review

- Dedicated customer support at every stage

For pre-submission enquiries, contact research@f1000.com 